\title{
Stable cross-sectional dimensions for navigation channel in the estuary of Sangatta River, Indonesia
}

\author{
Tommy Sutarto* \\ Politeknik Negeri Samarinda, Civil Engineering Department, 75131 Samarinda, Kalimantan Timur, Indonesia
}

\begin{abstract}
The objectives of this study are: 1) to capture the existing condition of the river channel in Sangatta River estuary, including the bathymetry of the river bed, and the cross-sectional dimensions of the river, 2) to design a stable navigation channel in Sangatta River estuary that allows less maintenance dredging and improves navigability of the channel during a critical condition when the water level is at the lowest, and 3) to test the effectiveness of the stable cross section in term of the availability of navigable depth. This research is divided into five stages, namely: 1) preparatory stage and preliminary survey, 2) main surveys, 3) hydrological and hydraulic analysis, 4) waterway design, and 5) dredging plan. The hydraulic analysis also includes determining the water level and depth profiles before and after dredging. HEC-RAS software is used to simulate, for each month, the water level and depth profiles in the channel at a critical condition when the sea water level is at low water spring (LWS) coincides with the river flow of $50 \%$ probability of occurrence, Q50. A stable channel for Sangatta River estuary is characterized with a bed slope, $\mathrm{S}=0.00015$, a flow depth, $\mathrm{D}=3.6 \mathrm{~m}$, a bed width, $\mathrm{b}=76.3 \mathrm{~m}$ and a sidewall slope, $\mathrm{m}=1.5$. The simulation results show that the stable cross sections of the river provide sufficient water depth for navigation, even during the critical condition.
\end{abstract}

\section{Introduction}

The depth of navigation channel is generally designed only based on vessel size without considering river morphodynamic processes, such as bank erosion [1, 2, $3]$, scouring, and siltation, which dictate the crosssectional dimensions of the river. More often, contribution of bank erosion to total sediment load and deposition in the channel are underestimated due to the difficulties of observing and measuring this process in the nature $[4,5]$. As a result, navigation channels often become shallow quickly and require more frequent dredging at a high cost [2].

Alluvial channel cross sections show minimum change in shape and size over time if their dimensions correspond to the dimensions of stable channel. An alluvial channel is in stable, regime or dynamic equilibrium state when the rate of sediment transport is approximately equivalent to the existing sediment load $[6,7]$, this regime is characterized by less bank erosion, i.e., mass failure and fluvial erosion [8], minimum scouring, siltation, and lateral migration.

Stable slope and cross-sectional dimensions can be predicted using various methods, based on dominant discharge and bed sediment size $[6,9,10]$. Dominant discharge can be estimated by analyzing historical flow and sediment transport data. Unfortunately, most of the time, those type of data are not available or lacking [11]. This is one of the reasons why the stable cross-sectional dimensions are rarely taken into consideration in determining the depth of navigation channels.
In this manuscript, a navigation channel is designed following stable channel dimensions. The effectiveness of that channel in term of the availability of navigable depth is tested. The dominant discharge is determined by analyzing the rainfall data which are well recorded. This method is applied at Sangatta River estuary, Indonesia.

Sangatta River is one of the main rivers that cross Kutai Timur Regency, Kalimantan Timur Province, Indonesia. More specifically, the river passes through three districts, namely Rantau Pulung, Sangatta Utara and Sangatta Selatan. The latter two districts are the center of government and economy in Kutai Timur Regency.

Sangatta River used to be an inland waterway for vessels transporting commodities, especially fish, into inland areas, such as Sangatta Utara and Sangatta Selatan, which are now growing into residential, government, and business centers. Unfortunately, severe siltation occurs at several reaches of the river, especially at the estuary. Here, the water depth is significantly reduced, making the river unnavigable more frequently, especially during the spring tide when the water level is at the lowest also called low water spring (LWS). This circumstance has even changed the portrait of the economic activity in Sangatta Utara and Sangatta Selatan.

Siltation has also significantly reduced the drainage capacity of the river. It is not uncommon the river overflow and inundate Sangatta Utara and Sangatta Selatan District.

\footnotetext{
* Corresponding author: tommysutarto@polnes.ac.id
} 
To solve the problems, it is necessary to dredge the river channel at the estuary of the Sangatta River. This effort will provide two benefits at once, i.e., restoring the required depth for navigation, and reducing the intensity of river floods at the middle stream reach, especially in strategic areas, e.g., Sangatta Utara and Sangatta Selatan.

Currently, local government is planning to dredge the Sangatta River, including the estuary of the river. However, there are no results of a mature study that can be referred to develop a reliable dredging plan.

This manuscript provides important information required for dredging the channel in the estuary of the Sangatta River. The objectives of this study are: 1) to capture the existing condition of the river channel in Sangatta River estuary, including the bathymetry of the river bed, and the cross-sectional dimensions of the river, 2) to design a stable navigation channel in Sangatta River estuary that allows less dredging and improves navigability of the channel during a critical condition when the water level is at the lowest, and 3) to test the effectiveness of the stable cross sections in term of the availability of navigable depth.

\section{Study site}

The dredging location is at the estuary of Sangatta River. The survey, river hydraulics study, and design is focused at this location (Figure 1). However, hydrological study involving the prediction of flood and average flow hydrographs certainly require collection of data at the Sangatta watershed scale (Figure 2).

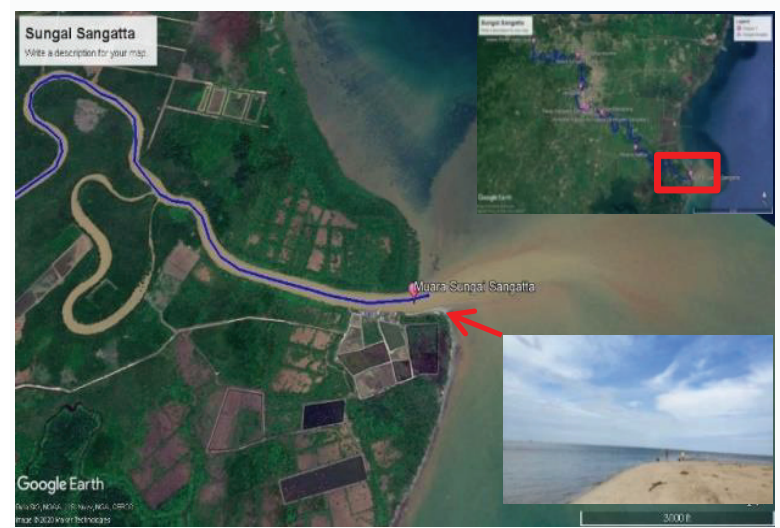

Fig. 1. Estuary of Sangatta River (Google Earth).

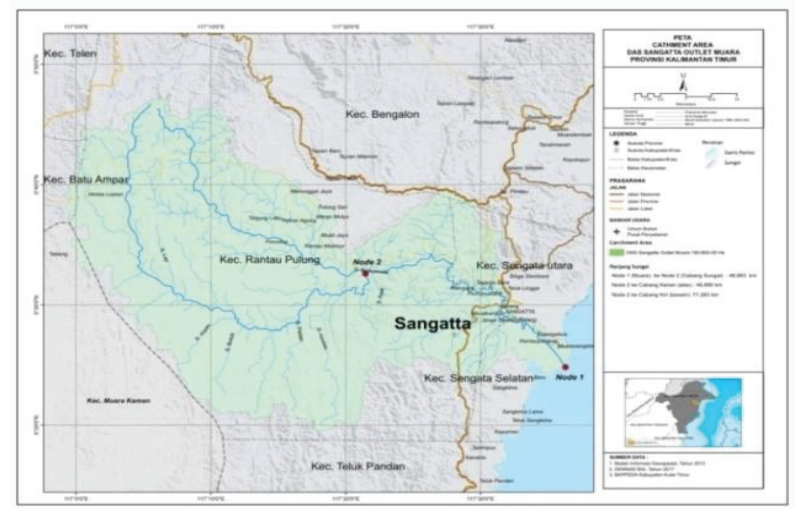

Fig. 2. Sangatta River basin.
The upstream and middle stream reaches of Sangatta River Basin are located in Rantau Pulung District, while the downstream reach is in Sangatta Utara and Sangatta Selatan District (Figure 2).

\section{Methodology}

This research is divided into five stages, namely: 1) preparatory stage and preliminary survey, 2) main surveys, 3) hydrological and hydraulics analysis, 4) waterway design, and 5) dredging plan.

The preparation stage consists of administrative preparation and technical preparation. Administrative preparations aim at forming a survey team and survey plan, as well as communicating with related agencies. Technical preparations include collecting supporting data such as map, tide table, and known topographic reference points, planning the sounding lines in the river, and determining the location of tidal observation stations, and scheduling for personnel and equipment mobilization.

A preliminary survey is conducted to picture the existing conditions of water body, riverbank, and riparian zone, and to identify any potential problems that could hamper survey activities later.

The next stage is the main surveys, which is focused on the estuary of the river. Here, a topographic survey of the riverbank is performed using a Total Station (Figure 3a). The topography of the riverbank is measured as far as $30 \mathrm{~m}$ from the riverbank toward the land, and $1200 \mathrm{~m}$ long from STA $0+000$ (the mouth of the river) upstream ward to STA $1+200$.

Also, a river bed bathymetric survey is conducted using echo sounding technique (Figure $3 b$ and $3 c$ ). Echo sounding was conducted on the $3^{\text {rd }}$ week of December 2020 along $1200 \mathrm{~m}$ from STA $0+000$ upstream ward to STA $1+200$. The water depth data, obtained from echo sounding technique, are corrected with the change in water level due to tide during measurement. For this reason, the water depth measurement is conducted simultaneously with tide observation (Figure $3 \mathrm{~d}$ ).
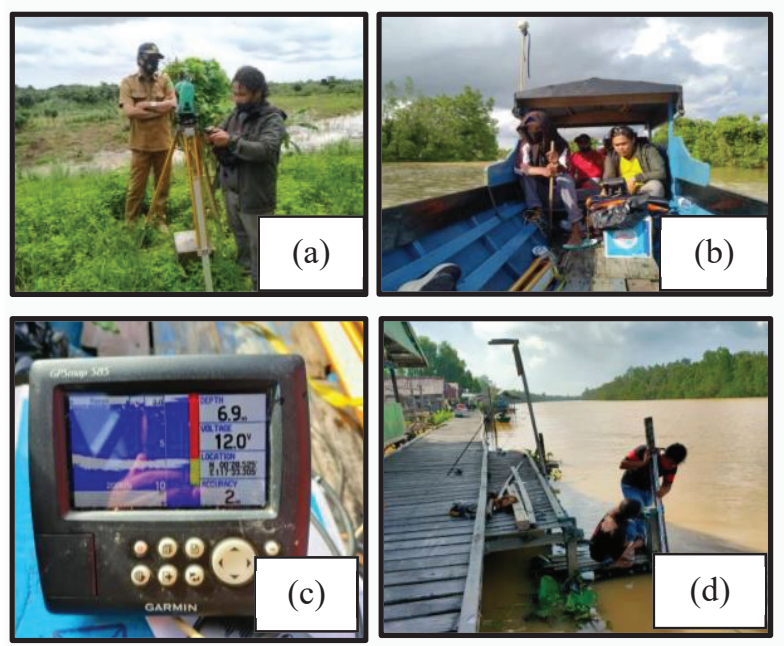

Fig. 3. Main surveys. a). Topographical survey. b) Bed bathymetry survey. c) Echo sounder. d) Peil scale for tide observation. 
Bed sediment is collected and brought to the laboratory for testing its gradation. The other concern in this phase is determining the safe disposal location for dredged material.

Furthermore, hydrological analysis is performed to determine the design rainfall depth, flood hydrograph, dominant discharge, potential evapotranspiration, and the average flow hydrograph in the estuary of the Sangatta River. Following hydrological analysis, hydraulic analysis is conducted to determine stable cross-sectional dimensions which are used as reference information for navigation channel design and dredging plan. The hydraulic analysis also includes determining the water level profile and channel depth before and after dredging. HEC-RAS software is used to simulate the water level profile in the channel, every month, corresponding to a critical condition which is represented by LWS level at the sea coincides with a flow of $50 \%$-probability of occurrence, $\mathrm{Q}_{50}$, in the channel.

The last two phases of the study, i.e. waterway design, and dredging plan. The dredging plan should address the dredging method, disposal location, volume, cost, and schedule. These are not discussed in this manuscript due to space limitation.

\section{Results and discussion}

\subsection{Channel bathymetry}

Figure $4 \mathrm{a}$ presents the contours of river bed obtained from bathymetric survey. Also, Figure $4 \mathrm{~b}$ demonstrates the longitudinal profile of riverbed and bank top obtained from bathymetric and topographic survey. The height of the river bank is between 3 and $5 \mathrm{~m}$. The thickness of siltation at the bed is increasing from the upstream (STA $1+200)$ to the mouth (STA $0+000)$. River sedimentation is seen to reach a thickness of up to $2.0 \mathrm{~m}$ at STA $0+000$.

\subsection{Rainfall depth}

Historical river flow data are not available for the studied reach because there is no measurement station near the location. Fortunately, the rainfall data is well recorded. In this study, the flood and average flow hydrograph are estimated from rainfall data with a rainfall-runoff model, e.g., synthetic unit hydrograph model. Descriptions on this method can be referred to $[12,13]$.

Frequency distribution analysis is performed for the daily rainfall data recorded in last 10 (ten) years, it is found that log-normal distribution can represent the frequency distribution of annual maximum daily rainfall in Sangatta watershed. The relation curve for maximum daily rainfall depth vs. return period is demonstrated in Figure 5. The rainfall depth of 2-year storm is equal to $76.49 \mathrm{~mm}$.
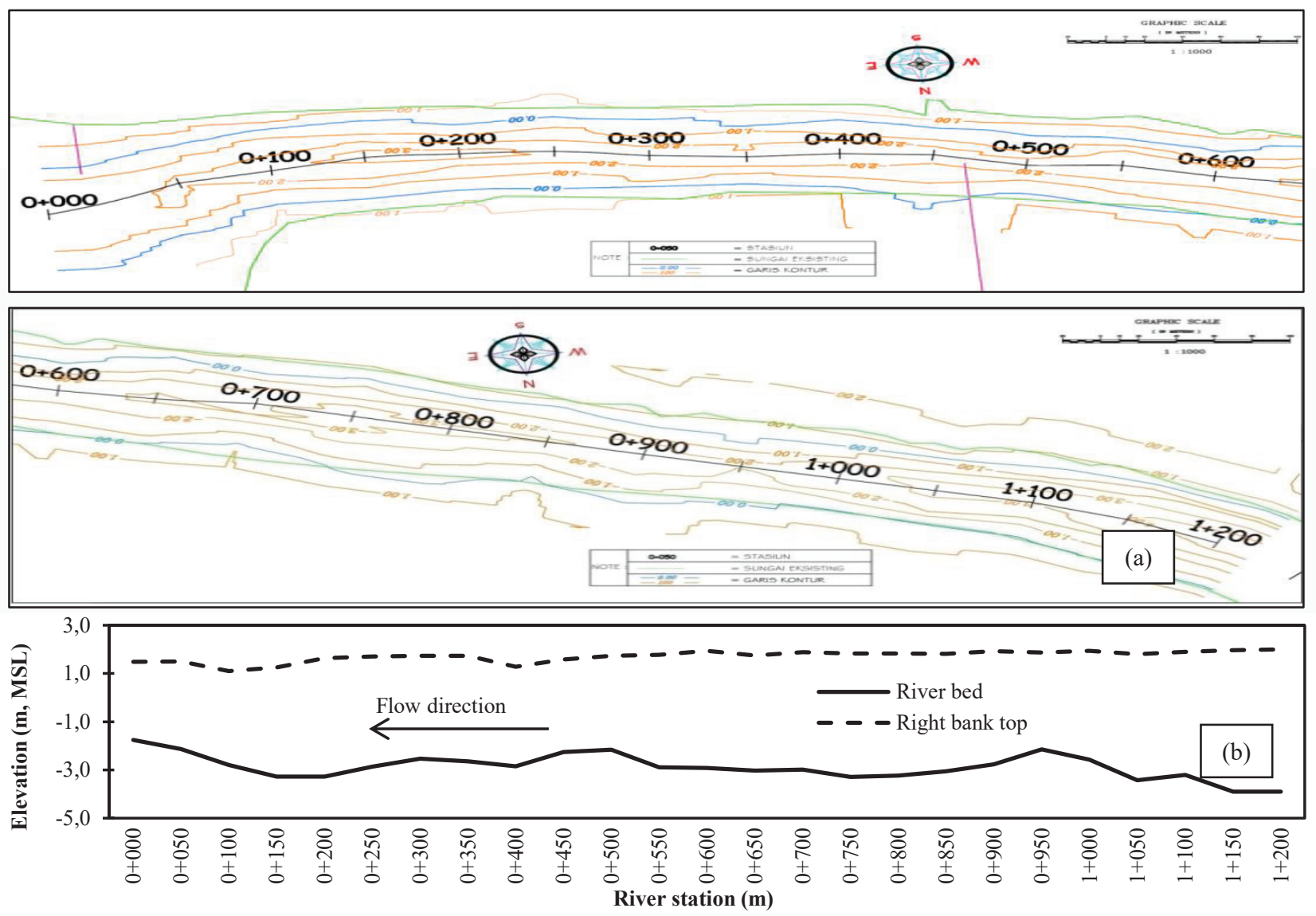

Fig. 4. Results of topographic and bathymetric surveys from STA 0+000 until STA 1+200. a) River bed contour b) Longitudinal profile of river bed and right bank top (December 2020). 


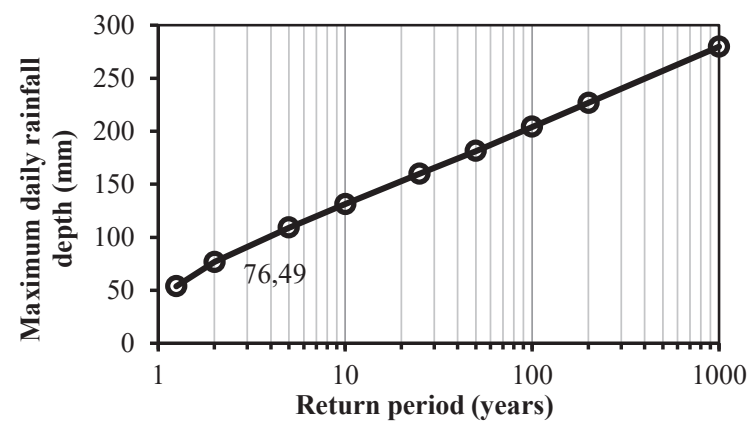

Fig. 5. The relation curve for maximum daily rainfall depth vs. return period in Sangatta watershed.

Hourly rainfall distribution can be estimated using Mononobe equation [14]:

$$
I_{t}=\frac{R}{T}\left(\frac{T}{t}\right)^{2 / 3}
$$

where: $I_{t}=$ average rainfall intensity from the initiation of rain up to time- $\mathrm{t}$ ( $\mathrm{mm} /$ hour), $T=$ duration of rain event (in this case 4 hours), dan $R=$ rainfall depth ( $\mathrm{mm}$ ).

Next, rainfall depth at time-t can be determined by:

$$
R_{t}=t I_{t}-(t-\Delta t) I_{(t-\Delta t)}
$$

where: $R_{t}=$ rainfall depth at time-t $(\mathrm{mm}), \Delta t=$ time interval (hour), $I_{t}=$ average rainfall intensity from the initiation of rain up to time-t (mm/hour), dan $I_{(t-\Delta t)}=$ average rainfall intensity from the initiation of rain up to time- $(t-\Delta t)$ (mm/hour).

After hitting the ground surface, a proportion of rain drops turn into runoff and flow into river, this proportion of rain is called effective rainfall, $R_{e}$. The other proportion of rain infiltrate underground and make a base flow. The effective rainfall, $R_{e}$, can be estimated by equation:

$$
R_{e}=C R
$$

where: $C=$ runoff coefficient whose value is largely determined by the type of land cover and cultivation. A table of $C$ values for various land cover is given in [15] and [16].

Using equations (1), (2) and (3) the hourly rainfall and infiltration distribution of 2-year storm is obtained as shown in Figure 6.

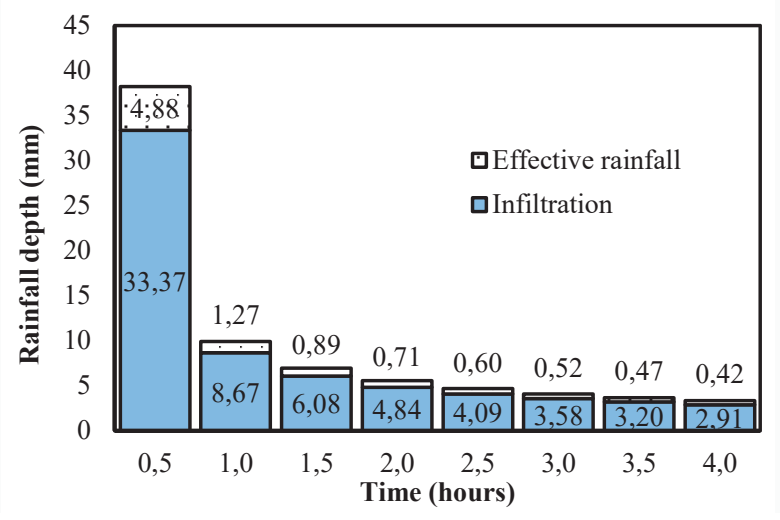

Fig. 6. A 76.49-mm rainfall depth (2-year storm) is distributed within 4-hour rain duration.

\subsection{Flood hydrograph}

The Nakayasu synthetic unit hydrograph model is used to develop a 2-year flood hydrograph for study site (Figure 7). The input parameters for this model are effective rainfall depth (Figure 6), area of watershed, and river length. A complete description of this procedure can be seen in [12], [13], [17], and [18]. Based on Figure 7, the peak flow for 2-year flood, $Q_{2 y r}$, is $423.78 \mathrm{~m}^{3} / \mathrm{s}$

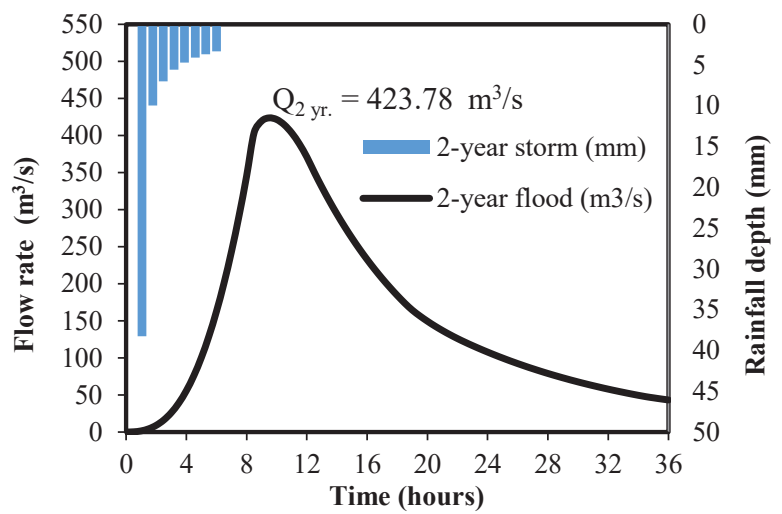

Fig. 7. A 2-year flood hydrograph for study site.

Earlier studies conducted in Indonesia, e.g., [18] and [19] have found that synthetic unit hydrograph model overestimated the peak flood by 30 to $50 \%$. This deviation could be attributed to the assumptions used to construct the unit hydrograph concept and the complexity of governing parameters, e.g. nature of rain, and watershed characteristics. For this reason, the peak flood is corrected to become $Q_{2 y r}=313.91 \mathrm{~m}^{3} / \mathrm{s}$ which is $35 \%$ less.

\subsection{Dominant discharge}

River dredging is intended to restore the stable crosssectional dimensions of the river. The dimension of the stable section is determined by the channel forming discharge which is equivalent to the dominant discharge, $Q_{d}$. Dominant discharge is the discharge that contributes the largest to the average annual sediment 
transport [20]. The $Q_{d}$ is estimated to be nearly equal to bank full discharge, $Q_{b}$, which is also equivalent to the 2-year flood, $Q_{2 y r}$. $[6,21-25]$. Shortly, it can be written $Q_{d} \approx Q_{b} \approx Q_{2 y r} \approx 313.91 \mathrm{~m}^{3} / \mathrm{s}$.

\subsection{Average flow}

The monthly average flow in the river is obtained using the hydrological model introduced by Mock [26]. This approach is implemented due to the fact that historical flow data are not available. Detail explanation on Mock model can be referred to [26-28]. Input parameters for the model are monthly rainfall depth, $P$, and potential evapotranspiration, $E T_{o}$. The monthly average flow hydrograph for the period 2009 to 2019 are shown in Figure 8.

\subsection{Flow of $50 \%$-probability of occurrence}

A flow with $50 \%$ probability of occurrence, $Q_{50}$, is the flow that has a chance to be equaled or exceeded as much as 50 percent. The probability of occurrence, $\mathrm{Pr}$, can be determined following the Weibull formula:

$$
\operatorname{Pr}=\left(1-\frac{m}{n+1}\right) \times 100
$$

In this equation, $\mathrm{Pr}=$ percent $(\%)$ probability that a given flow will be equaled or exceeded, $m=$ rank of the inflow value, with 1 being the smallest possible value, $n=$ total number of events or data points on record.
By ordering the average flow data from smallest to largest, and using equation (4), it is found that $Q_{50}$ correspond to the flow at rank $6(m=6)$ in Table 1 .

\subsection{Stable cross section}

The geometric variables that characterize a stable cross section are flow width, $B$, flow depth, $D$, and bed slope, $S$, [29]. These variables are dependent variables whose values are influenced by independent variables, namely dominant discharge, $Q_{d}$, and diameter of bed sediment, $d_{50}[6,7,10]$.

The bed slope, $S$, of a stable channel can be approximated by:

$$
S=\frac{f^{5 / 3}}{1830 Q_{d}^{1 / 6}}
$$

where: $Q_{d}=$ dominant discharge $\left(\mathrm{ft}^{3} / \mathrm{det}\right), f=$ silt factor, $f=1.6 d_{50}{ }^{1 / 2}$, and $d_{50}=$ bed sediment diameter $(\mathrm{mm})$.

Laboratory sieve and hydrometer tests for bed sediment samples give $d_{50}=0.55 \mathrm{~mm}$. Substituting $d_{50}$ $=0.55 \mathrm{~mm}$ and $Q_{d}=313.91 \mathrm{~m}^{3} / \mathrm{s}=11,085.63 \mathrm{ft}^{3} / \mathrm{s}$ into equation (6) gives $S=0.00015$.

Rational method developed by Chang $[9,30]$ is applied to determine the dimensions of stable channel. River cross section is considered to have a trapezoidal shape with side wall slope $\mathrm{V}: \mathrm{H}=1: 1.5$. Three parameters, namely $S, d_{50}$, and $Q_{d}$ are known parameters to compute the dependent parameters, i.e., $B$ and $D$ using these equations:

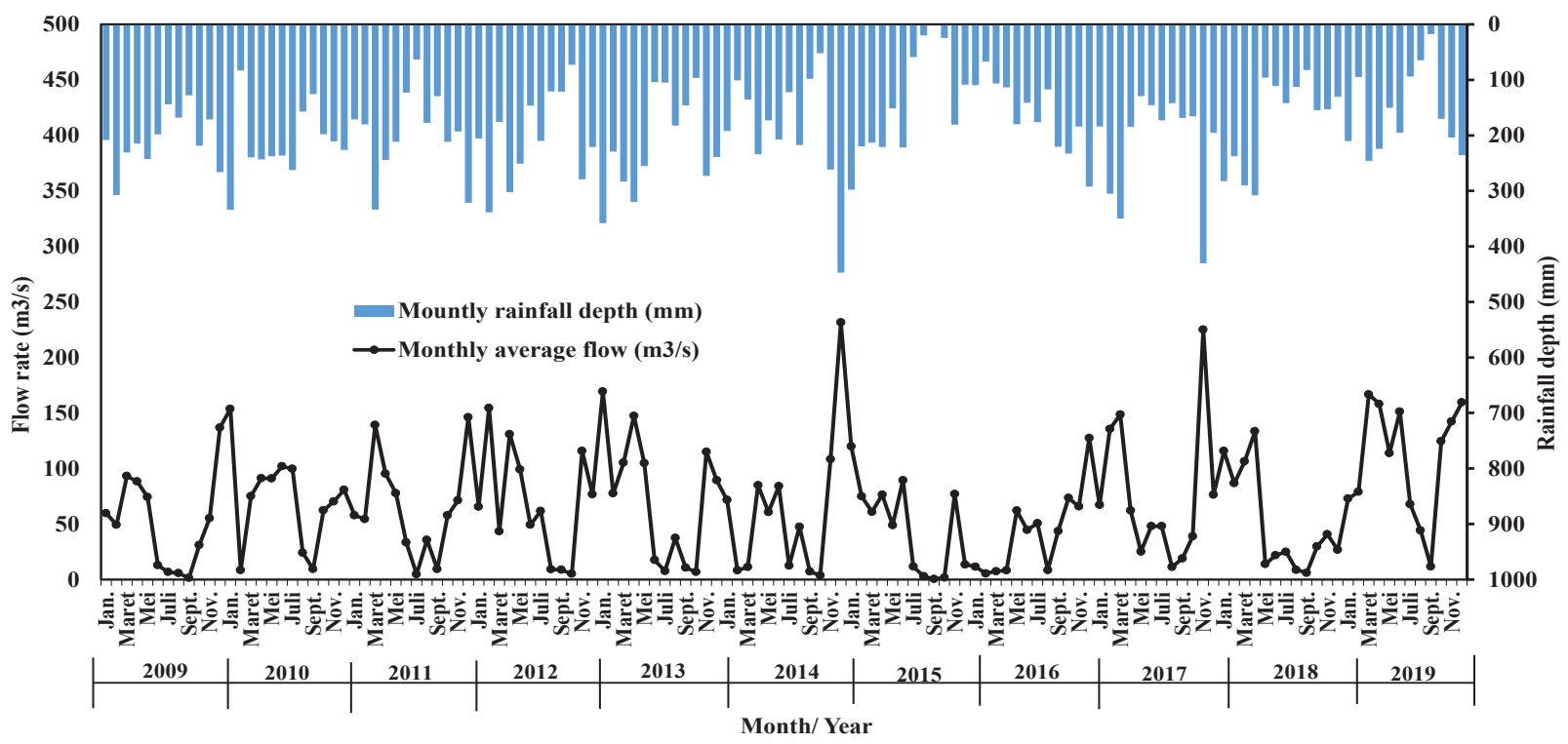

Fig. 8. Monthly rainfall depth and monthly average flow obtained from Mock hydrological model for the period 2009 - 2019 
Tabel 1. Determination of flow with $50 \%$ - probability of occurrence, $Q_{50}$.

\begin{tabular}{ccccccccccccc}
\hline \multirow{2}{*}{ Ranking } & \multicolumn{10}{c}{ Flow rate $\left(\mathbf{m}^{\mathbf{3}} / \mathbf{s}\right)$} \\
\cline { 2 - 13 } & Jan & Feb & Mar & Apr & Mei & Jun & Jul & Ags & Sep & Okt & Nov & Des \\
\hline 1 & 11.4 & 5.4 & 7.4 & 8.1 & 13.8 & 12.8 & 4.7 & 2.9 & 0.4 & 1.7 & 40.7 & 13.5 \\
2 & 57.9 & 8.2 & 11.2 & 62.0 & 25.0 & 17.4 & 6.7 & 5.6 & 1.3 & 3.6 & 55.2 & 26.7 \\
3 & 59.7 & 8.5 & 43.4 & 76.2 & 48.9 & 21.8 & 7.6 & 8.4 & 6.0 & 5.0 & 65.7 & 76.3 \\
4 & 65.6 & 49.2 & 60.9 & 85.0 & 60.6 & 33.3 & 11.6 & 8.6 & 7.2 & 6.7 & 70.3 & 76.6 \\
5 & 67.1 & 54.3 & 75.1 & 88.3 & 62.1 & 44.6 & 12.4 & 9.1 & 8.8 & 29.7 & 71.1 & 80.7 \\
$\boldsymbol{6}$ & $\mathbf{7 1 . 6}$ & $\mathbf{7 4 . 9}$ & $\mathbf{9 3 . 1}$ & $\mathbf{9 1 . 2}$ & $\mathbf{7 4 . 2}$ & $\mathbf{4 8 . 0}$ & $\mathbf{2 4 . 9}$ & $\mathbf{1 1 . 2}$ & $\mathbf{9 . 3}$ & $\mathbf{3 1 . 0}$ & $\mathbf{7 6 . 9}$ & $\mathbf{8 9 . 3}$ \\
7 & 72.8 & 77.5 & 105.1 & 95.2 & 77.8 & 49.2 & 48.0 & 24.1 & 9.3 & 38.8 & 108.2 & 127.3 \\
8 & 115.7 & 78.9 & 106.4 & 130.9 & 90.9 & 84.0 & 50.6 & 35.7 & 10.6 & 57.7 & 115.0 & 136.8 \\
9 & 119.9 & 86.6 & 139.1 & 133.5 & 99.2 & 89.4 & 61.7 & 37.4 & 11.5 & 62.2 & 115.8 & 146.1 \\
10 & 153.6 & 135.6 & 148.5 & 147.4 & 104.9 & 101.9 & 67.7 & 44.2 & 18.8 & 73.4 & 142.2 & 159.4 \\
11 & 169.2 & 154.5 & 166.7 & 158.1 & 113.8 & 151.2 & 99.7 & 47.5 & 43.6 & 124.6 & 225.0 & 231.5 \\
\hline $\boldsymbol{Q}_{\mathbf{5 0}}\left(\boldsymbol{m}^{3} / \mathbf{s}\right)$ & $\mathbf{7 1 . 6}$ & $\mathbf{7 4 . 9}$ & $\mathbf{9 3 . 1}$ & $\mathbf{9 1 . 2}$ & $\mathbf{7 4 . 2}$ & $\mathbf{4 8 . 0}$ & $\mathbf{2 4 . 9}$ & $\mathbf{1 1 . 2}$ & $\mathbf{9 . 3}$ & $\mathbf{3 1 . 0}$ & $\mathbf{7 6 . 9}$ & $\mathbf{8 9 . 3}$ \\
\hline
\end{tabular}

$$
\begin{gathered}
\frac{S_{c}}{d_{50}{ }^{1 / 2}}=\frac{0.00238}{Q_{d}{ }^{0.51}} \\
B=4.17\left(\frac{s}{d_{50}{ }^{1 / 2}}-\frac{S_{c}}{d_{50}{ }^{1 / 2}}\right)^{0,05} Q_{d}{ }^{0,5} \\
D=0.055\left(\frac{s}{d_{50^{1 / 2}}}-\frac{S_{c}}{d_{50^{1 / 2}}}\right)^{-0,3} Q_{d}^{0,3}
\end{gathered}
$$

where: $S_{c}=$ critical bed slope corresponding to bed load threshold, $B$ and $D$ are in feet.

Substituting $d_{50}=0.55 \mathrm{~mm}, S=0.00015$ and $Q_{d}=$ $11,085.63 \mathrm{ft}^{3} / \mathrm{s}$ into equation (6), (7), dan (8) give $B$ equals $285.83 \mathrm{ft}$ or $87.12 \mathrm{~m}$, and $D$ equals $11.81 \mathrm{ft}$ or $3.6 \mathrm{~m}$.

\subsection{Required navigation depth}

It is expected the water depth in Sangatta River estuary is still sufficient for fishing vessels of 30-Gross Tonnage (GT) to navigate even when the water surface is at the lowest level in the channel. A 30-GT vessel typically has a total length (LOA) of $18.5 \mathrm{~m}$, a width of $4.5 \mathrm{~m}$, and a draft of $1.5 \mathrm{~m} \mathrm{[31].}$

The water surface, in the channel, is at the lowest level when the sea water level is at low water spring (LWS) coincides with the river flow rate that is equal to $\mathrm{Q}_{50}$.

The required navigation depth, $H$, can be determined as (Figure 9) [32]:

$$
\begin{aligned}
& H=d+\left(\text { the largest among } R \text { or } G_{g}\right)+G_{s}+S+ \\
& \quad P+K
\end{aligned}
$$

where: $d=$ draft, $R=$ net free space, $G_{g}=$ vertical movement due to wave (about 0.3 times wave height), $G_{s}=$ vertical movement due to squat $=k V, k=$ coefficient influenced by vessel size, $V=$ navigation speed $\mathrm{km} / \mathrm{jam}, S=$ siltation depth between two successive dredging, approximate error in dredging, $P=$ $0.05 \mathrm{~m}$, and dredging tolerance, $K=0.10 \mathrm{~m}$.

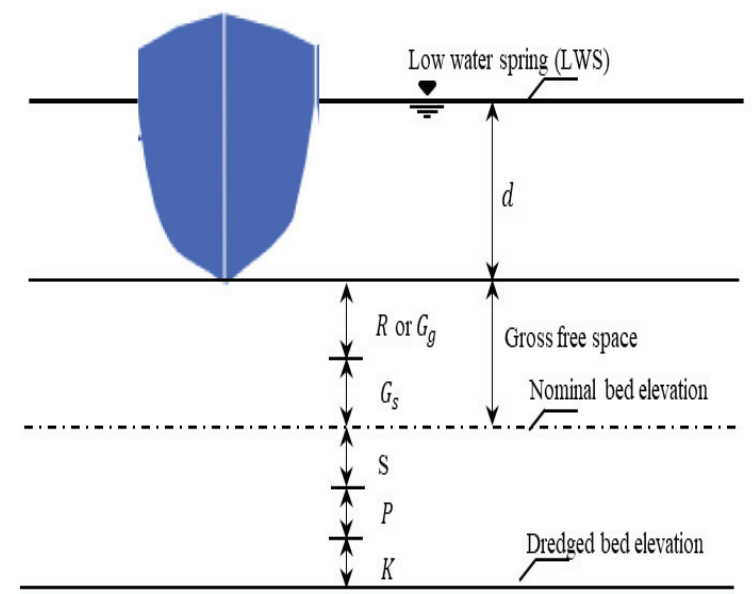

Fig. 9. Water depth for river navigation.

Given LOA $<86 \mathrm{~m}$ and river bed is dominated by sands, then the $R$ value is equal to $0.2 \mathrm{~m}$ [32]. If the allowable speed, $V$, for navigating the channel is $6 \mathrm{knot}$ or $11.112 \mathrm{~km} /$ hour, then the wave height is $0.286 \mathrm{~m}$ and $G_{g}=0.3 \times 0.286=0.086 \mathrm{~m} \mathrm{[32].} \mathrm{For} \mathrm{a} \mathrm{vessel} \mathrm{with} \mathrm{LOA}$ $<86 \mathrm{~m}$, the $k$ equals 0.017 , and $G_{S}=0.017 \times 11.112=$ $0,189 \mathrm{~m}$ [32]. Given $S=0.4 \mathrm{~m}, P=0.02 \mathrm{~m}$ and $K=$ $0.10 \mathrm{~m}$, substitute those values into equation (9) to obtain the required navigation depth $H=1.5+0.2+$ $0.189+0.4+0.02+0.10=2.41 \mathrm{~m}$.

\subsection{Available water depth in critical condition}

HEC-RAS software is used to model the surface water profile and water depth in the channel, before and after maintenance dredging, at the lowest water level that occurs when the sea water level is at LWS level coincides with the river flow rate that is equal to $\mathrm{Q}_{50}$.

Initially, the geometry of the channel, from STA $0+100$ until STA $1+200$, is modeled. This includes modeling the channel reach, cross sections, and surface roughness. A georeferenced aerial image is used to facilitate the depiction of channel reach (Figure 10a) and cross sections (Figure 10b). The geometries of pre- 
dredged cross sections are obtained from the survey, while the dimensions of post-dredged cross sections follow the stable channel dimensions.

Next, 1D steady flow modeling is performed 12 times, each representing the flow conditions per month from January to December. The $Q_{50}$ value (Table 1) is entered as an inflow at the upstream end, namely STA $1+200$. The upstream boundary condition is the normal water level for a bed slope of 0.00015, while the downstream boundary condition is the water level at LWS level. The LWS level per month is presented in Figure 11, obtained from TNI-AL Hydro-Oceanography Service (2020). The lowest LWS is $-1.5 \mathrm{~m}(\mathrm{msl})$ or 1,5 $\mathrm{m}$ below mean sea level. This occurs in March and October (Figure 11).

Figure 12 presents a comparison of channel crosssection modeled in HEC-RAS between pre-dredging and post-dredging condition at river station STA $0+100$. The pre-dredged cross section is obtained from the survey, while the dimensions of post-dredged cross sections follow the stable channel dimensions.
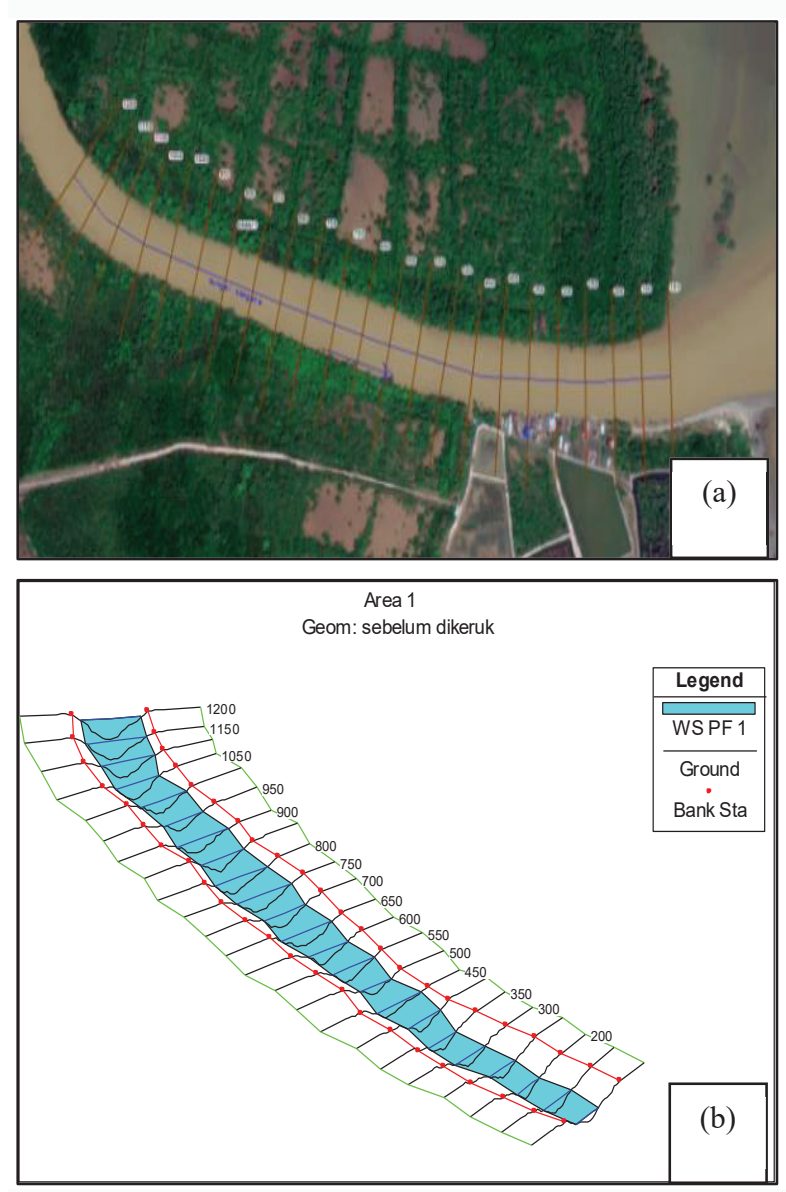

Fig. 10. Channel geometry modeling. a) Georeferenced aerial image is used to draw the channel reach. b) Channel cross sections from STA $0+100$ to $1+200$.

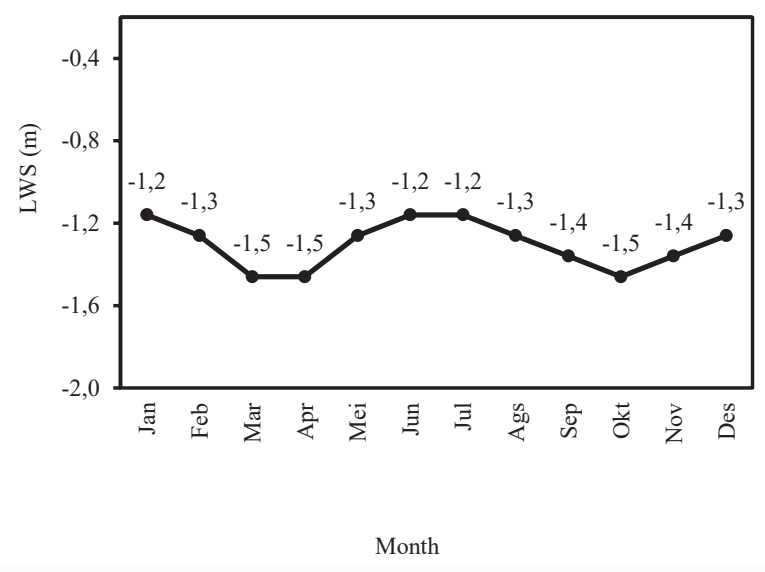

Fig. 11. Low water spring (LWS) elevation per month.

Figure 12 presents a comparison of channel crosssection modeled in HEC-RAS between pre-dredging and post-dredging condition at river station STA $0+100$. The pre-dredged cross section is obtained from the survey, while the dimensions of post-dredged cross sections follow the stable channel dimensions.

Also, Figure 12 demonstrates a comparison of water depth, for each month, between pre-dredging and postdredging condition obtained from HEC-RAS simulations. The figure presents only the simulation results from January until April due to space limitation. It can be observed, the water depth significantly increases after maintenance dredging.

Figure 13 shows a comparative graph of water depth before and after dredging at STA $0+100$ from January to December. It shows the lowest depth is $1.29 \mathrm{~m}$ before dredging and $2.56 \mathrm{~m}$ after dredging. Both occurred in October. Also, the water depth significantly increases, by a factor of 2 , after maintenance dredging.

Figure 14 shows longitudinal profile of channel bed and water surface before and after maintenance dredging for the critical condition in October. Note, before dredging, the bed elevation is high, especially at STA $0+000$ and $0+050$, such that the bed and water level almost coincide, creating a very limited water depth along the channel. This condition indicates siltation has occurred in the channel making it unnavigable.

On the other hand, the post-dredged channel geometry characterized by stable slope and cross sectional dimensions and lowered bed elevation has improved the water depth along the channel. Also note, there is a decrease in water level up to $0.6 \mathrm{~m}$ due to bed lowering, this is obviously has a positive impact on flood control at the middle stream. 


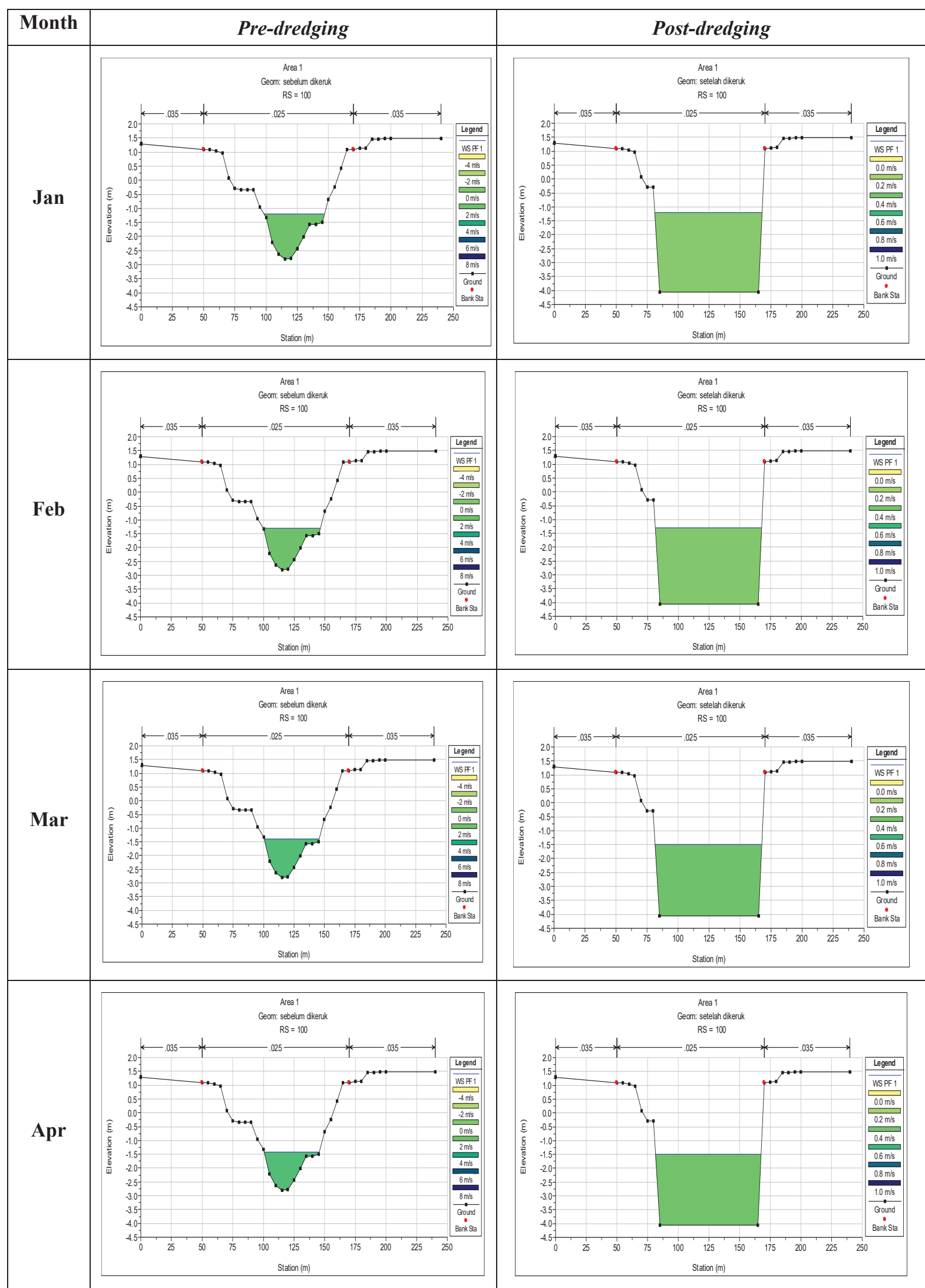

Fig. 12. Cross-section and water-depth comparison between pre-dredging and post-dredging condition at river station STA $0+100$ for a critical condition when the water surface, in the channel, is at the lowest level. 


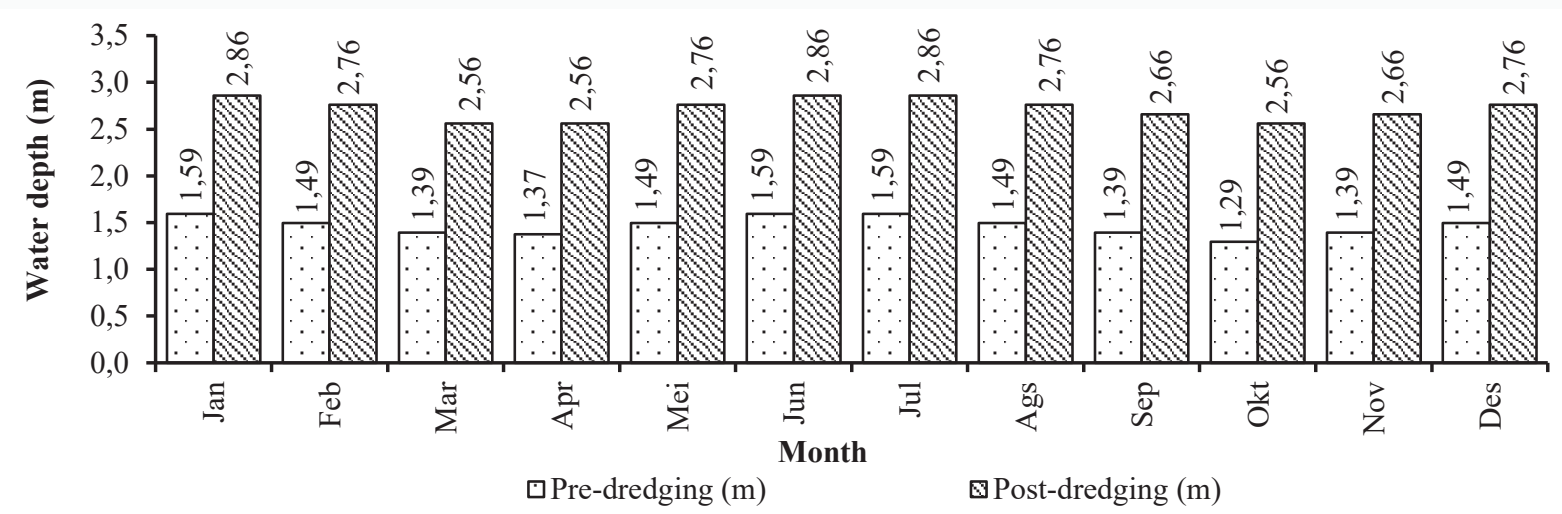

Fig. 13. A water depth comparison between pre-dredging and post-dredging at river station STA $0+100$ for the critical condition.

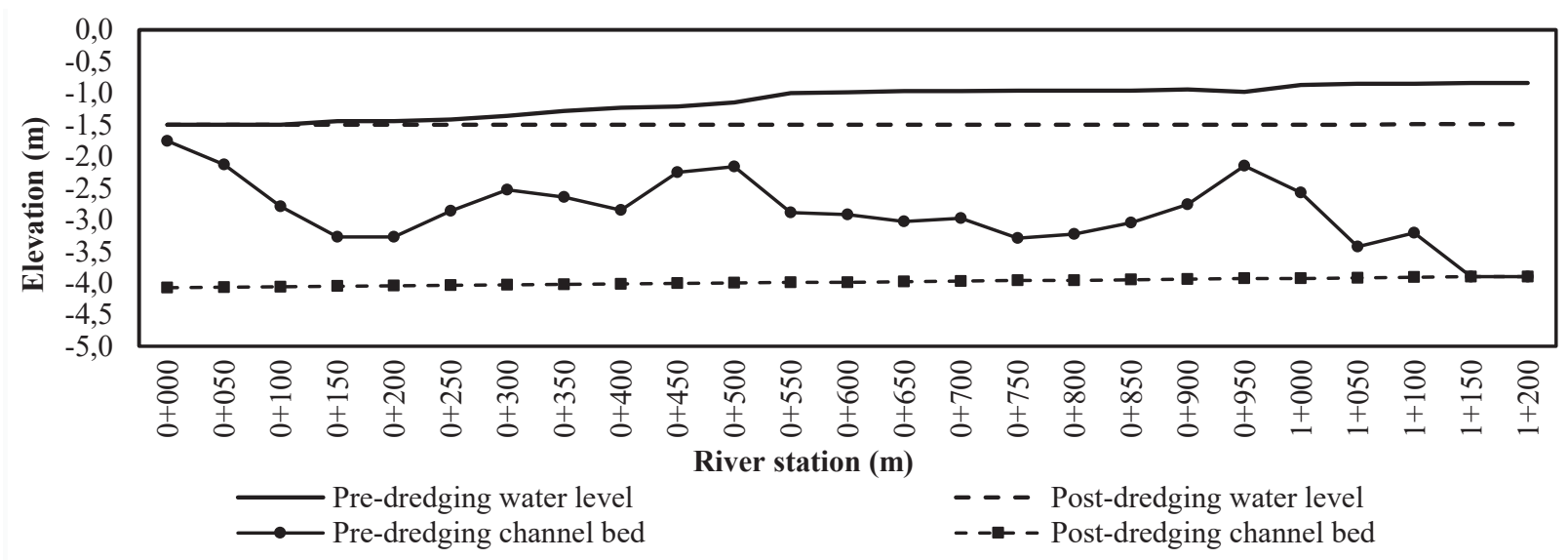

Fig. 14. Longitudinal profile of channel bed and water surface before and after dredging for the critical condition in October.

\subsection{The effectiveness of stable cross sections}

The effectiveness of stable cross-sections in term of providing required navigation depth $(H=2.41 \mathrm{~m})$ is tested, especially for a critical condition when the water surface is at the lowest level in October.

Figure 15 portrays a comparison among predredging and post-dredging water depth in the channel, as well as required navigation depth. Prior to dredging, the water depth is insufficient for 30-Gross-Tonage fishing vessel to navigate. This circumstance occurs in almost all river stations, except STA $1+050,1+150$ and $1+200$. The minimum depth is $0.26 \mathrm{~m}$ at STA $0+000$.

An opposite situation occurs as the geometry of the channel follows the stable slope and cross-sectional dimensions, herein represented by post-dredged cross sections. The water depths at all river stations are greater than or equal to the required navigation depth $(H=2.41$ $\mathrm{m}$, Figure 15). The lowest water depth is $2.41 \mathrm{~m}$ at STA $1+150$ and $1+200$. Thus, the stable slope and stable cross-sectional dimensions are acceptable and they can be referred for developing navigation channel in Sangatta River estuary

It is also interesting to observe that the water depth decreases after dredging at STA $1+050,1+150$, and $1+200$. This can be attributed to the lowering of water level as an implication of the decrease in bed elevation. This drop in water level certainly has a positive impact on controlling floods at the middle stream.

\section{Conclusions}

The siltation in Sangatta River estuary has reached a thickness up to $2 \mathrm{~m}$ based on bathymetric survey conducted in December 2020. This situation has caused Sangatta River estuary unnavigable more frequently, especially when the water surface is at the lowest level during the spring tide in October. In this state, the minimum water depth is only $0.26 \mathrm{~m}$ much less than the required navigation depth for a 30 -Gross-Tonage fishing vessel, $(H=2.41 \mathrm{~m})$.

The stable channel geometry for Sangatta River estuary is characterized with the following dimensions: bed slope, $\mathrm{S}=0.00015$, water depth, $\mathrm{D}=3.6 \mathrm{~m}$, bed width, $\mathrm{b}=76.3 \mathrm{~m}$ and side wall slope, $\mathrm{m}=1.5$.

The results of HEC-RAS models show that the water depth in the channel is sufficient for a 30-Gross-Tonage fishing vessel to navigate, even when water surface is at the lowest level, if the channel geometry follows the stable slope and stable cross-sectional dimensions. Thus, the dimensions of stable channel are acceptable and they can be referred for developing navigation channel in Sangatta River estuary. 


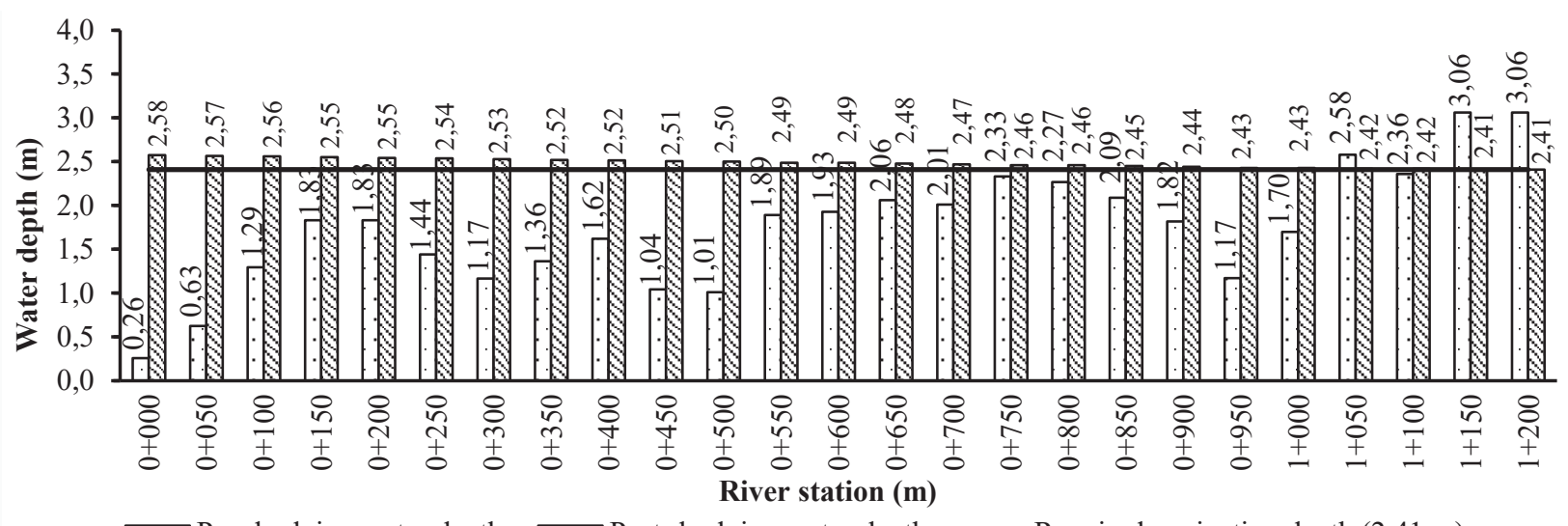

Fig. 15. A comparison among pre-dredging, post dredging, and required water depth for the critical condition in October.

\section{Acknowledgements}

This study is part of a project entitled Survey, Investigation, and Design (SID) for Sangatta River Normalization funded by Office of Public Works and Public Housing, Kalimantan Timur, Indonesia under contract No. 602/Bid-SDA/KPA/989.M/XI/2020, 10 November 2020.

\section{References}

1. A.N.T. Papanicolaou, T.E. Sutarto, C.G. Wilson, E.J. Langendoen, Bank stability analysis for fluvial erosion and mass failure, in Proceedings of the 2014 World Environmental and Water Resources Congress, 2014, pp. 1497-1508 (2014).

2. V.T. Nguyen, J.h. Zheng, J.s., Zhang, Water Science and Engineering 6(2), 178-188 (2013).

3. T.E. Sutarto, A.N.T. Papanicolaou, C.G. Wilson, IOP Conference Series: Earth and Environmental Science 451(1), 012093 (2020). doi:10.1088/17551315/451/1/012093.

4. A.N.T. Papanicolaou, C.G. Wilson, A.G. Tsakiris, T.E. Sutarto, F. Bertrand, M.,Rinaldi, S. Dey, E. Langendoen, Earth Surface Processes and Landforms 42(11), 1717-1732 (2017).

5. T.E. Sutarto, A short review on various techniques for measuring stream bank soil erosion strength, in Proceedings of 2018 International Conference on Applied Science and Technology, iCAST, 2018, pp.252-258 (2018). doi: 10.1109/iCAST1.2018.8751560.

6. P.Y. Julien, River Mechanics, p. 158 (University Press, Cambridge, UK., 2002).

7. R.J. Garde, K.G.R. Raju, Mechanics of Sediment Transportation and Alluvial Stream Problems (Willy Eastern Limited, New Delhi, 1977)

8. T.E.Sutarto, Procedia Engineering (125), 368-375 (2015).
9. H.H. Chang, Journal of Hydraulic Divison 106(HY5): 873-891 (1980).

10. S. Shaghaghi, H. Bonakdari, A. Gholami, O. Kisi, J. Shiri, A.D. Binns, B. Gharabaghi, Journal of Hydrology (2018), doi: https:// doi.org/10.1016/j.jhydrol.2018.09.057.

11. A.W. Salami, S.O. Bilewu, A.M. Ayanshola, and S.F. Oritola, Journal of American Science 5(4):2332 (2009).

12. D.A. Chin, Water Resources Engineering, $2^{\text {nd }}$ ed. (Pearson Prentice Hall, USA, 2006).

13. L.W. Mays, Water Resources Engineering. $1^{\text {st }}$ ed. (John Willey \& Sons, Inc., USA, 2001).

14. S. Priambodo, Suhardjono, L. Montarcih, and E. Suhartanto, MATEC Web of Conferences 276, 04012 (2019).

15. V. Novotny and H. Olem, Water Quality: Prevention, Identification, and Management of Diffuse Pollution (John Wiley \& Sons, Inc., New York, 1994).

16. C. Asdak, Hidrologi Dan Pengelolaan Daerah Aliran Sungai (Gajah Mada University Press, Yogyakarta, 2007), ISBN: 979-420-737-3.

17. C.D. Soemarto, Hidrologi Teknik, $2^{\text {nd }}$ ed. (Penerbit Erlangga, Jakarta, 1993).

18. I.G. Tunas, Pengembangan model hidrograf satuan sintetik berdasarkan kharakteristik fraktal daerah aliran sungai, Dissertation, (Institut Teknologi Sepuluh November, Surabaya, 2017).

19. N.F. Margini, D.A.G Nusantara, M.B. Ansori, Jurnal Teknik Hidroteknik, 2(1), 41-45 (2017).

20. M.G. Wolman, J.P. Miller, Journal of Geology 68, 54-74 (1960).

21. E. D. Andrews, J. of Hydrology, 46, 311-330 (1980).

22. L.B. Leopold, A View of the River, p. 290 (Harward University Press, 1994).

23. F.D. Shields, R.R. Copeland, P.C. Klingenman, M.W. Doyle, A. Simon, J. of Hydraulic Engineering, 129, 575-584 (2003). 
24. Ministry of Public Works Republic of Indonesia, Modul Dasar-Dasar Perencanaan Banjir Pelatihan Pengendalian Banjir, Pusat Pendidikan dan Pelatihaan Sumber Daya Air dan Konstruksi PUPR (2017).

25. V. Ferro, P. Porto, Geomorphology 139-140, 313321 (2012).

26. F.J. Mock, Land Capability Appraisal Indonesia: Water Availability Appraisal. Basic Study Prepared for the FAO/UNDP Land Capability Appraisal Project, AGL: SF/INS/72/011 Basic Study I. Bogor: UNDP-FAO Of The United Nations (1973).

27. S.S. Sachro, Sugianto, H. Budieny, Media Komunikasi Teknik Sipil 19 (1) (2013).

28. I. Komariah, and T. Matsumoto, Journal of Water Environment Technology, 17(4), 203-217 (2019).

29. H. Afzalimehr, M. Abdolhosseini, V.P. Singh, J. Hydrol Eng. 15(10), 859-864 (2010). doi: 10.1061/(ASCE) HE.1943- 5584.0000260.

30. H.H. Chang, Journal of Irrigation and Drainage Engineering, 111(1), 36-43 (1985).

31. B. Triatmodjo, Perencanaan Pelabuhan. p. 143-147 (Beta Offset, Yogyakarta, 2010).

32. Ministry of Transportation Republic of Indonesia, Laporan Akhir studi standarisasi di bidang lalu lintas dan angkutan transportasi ASDP (2010). 